\title{
KAJIAN PERSEBARAN SPASIAL KUALITAS AIR SUNGAI KARANG MUMUS, SAMARINDA, KALIMANTAN TIMUR
}

\section{Analysis Spatial Distribution of Water Quality in Karang Mumus River, Samarinda, Kaliman- tan Timur}

\author{
Vita Pramaningsih ${ }^{\mathrm{a}, \mathrm{b}}$, Slamet Suprayogic, Ig. L. Setyawan Purnama ${ }^{\mathrm{c}}$ \\ ${ }^{a}$ Program Studi Ilmu Lingkungan, Sekolah Pascasarjana, Universitas Gadjah Mada, Yogyakarta 55281 \\ —vitapramaningsih21@gmail.com \\ ${ }^{b}$ Universitas Muhammadiyah Kalimantan Timur, Samarinda 75124 \\ ${ }^{c}$ Departemen Geografi Lingkungan, Fakultas Geografi, Universitas Gadjah Mada, Yogyakarta 55281
}

\begin{abstract}
Problem of river pollution caused domestic waste human activity as residences, home industries and market. Karang Mumus River is Subwatershed Mahakam through Samarinda City. Purpose of this research is to analysethe spatial distribution of Karang Mumus River pollution, namely BOD, COD and TSS. Method used field survey, water sampling each river segment, laboratory analysis and make spatial distribution of pollution by ArcGIS application. Result of this research is to find the highest $B O D, C O D$ and TSS content on the residence side especially in flood plain area, home industries of tofu-tempeh and urban activity such as market, hospital, and Mall. Spatial distribution of BOD and COD find upstream and downstream has high content, then TSS hight content find in downstream area. Dominant activity in upstream area are home industries tofu-tempeh and in the downstream area are many residence in the flood plain area with their activity and also urban area.
\end{abstract}

Keywords: $B O D$, COD, domestic waste, spatial distribution, TSS

(Diterima: 13-02-2017; Disetujui: 22-09-2017)

\section{Pendahuluan}

Sungai Karang Mumus merupakan anak Sungai Mahakam yang membelah Kota Samarinda, Kalimantan Timur. Hulu sungai merupakan Bendungan Benanga yang dimanfaatkan untuk pengendali banjir Kota Samarinda. Pemukiman dan aktivitas sosial masyarakat tidak terlalu banyak. Penggunaan lahan didominasi untuk pertanian tanaman pangan dan sedikit peternakan masyarakat. Sungai terlihat bersih dari sampah dan tidak terdapat pemukiman di bantaran sungai.. Pemukiman mulai padat di bagian tengah Sungai dengan aktivitas sosial ekonomi yang semakin beragam. Pusat kota Samarinda berada disini, banyak dijumpai pasar, pusat perbelanjaan, Rumah Sakit dan hotel. Kondisi sungai kotor banyak sampah, air keruh dan berbau. Banyak penduduk di pemukiman pada bantaran sungai yang melakukan kegiatan Mandi, Cuci, Kakus (MCK) di sungai. Hal ini menyebabkan pencemaran air sungai karena masuknya limbah domestik ke dalam perairan. Hilir Sungai Karang Mumus bermuara ke Sungai Mahakam dan di pengaruhi pasang surut dari Sungai Mahakam. Kondisi sungai terlihat bersih dan aliran tenang. Kapal kecil terlihat disini untuk transportasi karena di dekat muara Sungai Karang Mumus merupakan pelabuhan. Penggunaan lahan didominasi pemukiman padat penduduk. Pemukiman di bantaran tidak terlihat karena sudah dilakukan relokasi sehingga bantaran sungai terlihat lebih tertata dan sungai terlihat lebih lebar. Pencemaran domestik dari pemukiman di bantaran dan pendangkalan mulai berkurang.
Menurut Sumendar (2012) besarnya pengaruh limbah cair batu bara di Sungai Karang Mumus tercemar sedang sampai tercemar berat. Sungai Karang Mumus masuk status mutu air kelas II. Menurut Yuliana (2013) masyarakat bantaran Sungai Karang Mumus khusus Kelurahan Bandara, Samarinda mengetahui kondisi kualitas air sungai buruk tetapi tetap memanfaatkannya untuk MCK (Mandi Cuci Kakus) karena belum memiliki PDAM(Perusahaan Daerah Air Minum).Faktor yang mempengaruhi kualitas air sungai, antara lain aktivitas membuang sampah, limbah cair dan penggunaan jamban di atas sungai. Pemerintah belum mampu mengatasi relokasi masyarakat di bantaran sungai terutama Kelurahan Sidomulyo, Kecamatan Samarinda Ilir (daerah Kehewanan). Kualitas air Sungai Karang Mumus di daerah ini, menurut data Badan Lingkungan Hidup Kota Samarinda dari tahun 2009 sampai 2012 dalam keadaan tercemar (Yumita et al., 2014). Berdasarkan permasalahan di Sungai Karang Mumus, penelitian ini bertujuan untuk menganalisis sebaran spasial kualitas air sungai untuk parameter BOD(Biological Oxigen Demand), COD (Chemical Oxigen Demand) dan TSS (Total Suspended Solid).

Kualitas air sungai dipengaruhi kecepatan aliran sungai dan bermacam aktivitas di bantaran sungai (Effendi, 2015). Kadar BOD, COD di sungai merupakan indikator adanya sumber pencemar organik seperti dari pertanian dan limbah domestik perumahan (Venkatesharaju et al., 2010).Kadar DO (Dissolved Oxigen) rendah, BOD tinggi dan nitrat tinggi merupa- 
kan indikator perairan terjadi eutrofikasi (Yogendraet al., 2008).

Kualitas fisik, kimia air untuk parameter $\mathrm{pH}$, TSS, BOD, COD, nitrat dan phospor di sungai dipengaruhi aktifitas sosial seperti industri, urbanisasi dan pertanian (Yadav et al., 2011). Hasil pemeriksaan kualitas air sungai secara fisik, kimia dan bakteriologi di daerah pariwisata di India menunjukan tidak memenuhi syarat dan dinyatakan tercemar (Kumaret al., 2010). Kualitas air sungai di hulu dengan penggunaan lahan sebagai perkotaan menunjukan kualitas air secara fisik tercemar dan tidak layak konsumsi di daerah hilir (Kalavathyet al., 2011).

Selain limbah domestik, limbah industri juga mempengaruhi kualitas air sungai untuk parameter BOD, COD, TSS dan Coliform karena mengandung limbah organik (Kanu et al., 2011).Kualitas air sungai untuk parameter $\mathrm{Fe}, \mathrm{Mn}, \mathrm{COD}$ dan TSS tinggi dipengaruhi buangan industri, limbah rumah tangga, pertanian dan run off dari daerah perkotaan (Yisaet al., 2010).

Perilaku masyarakat membuang sampah dan limbah domestik serta padatnya pemukiman di bantaran dengan kegiatan MCK di sungai menyebabkan kualitas air sungai menurun. Aktivitas sosial ekonomi seperti pasar, Industri Kecil dan Menengah, RS, Hotel yang menghasilkan limbah cair dan sampah berpotensi menyumbangkan beban pencemaran sungai.

\section{Metode}

Lokasi penelitian di Sungai Karang Mumus, Samarinda, Kalimantan Timur, Gambar 1. Waktu penelitian bulan Maret 2016. Alat yang digunakan botol sampel, cool box, perlengkapan pengambilan sampel dan kamera. Bahan yang digunakan peta Sub DAS Karang Mumus.

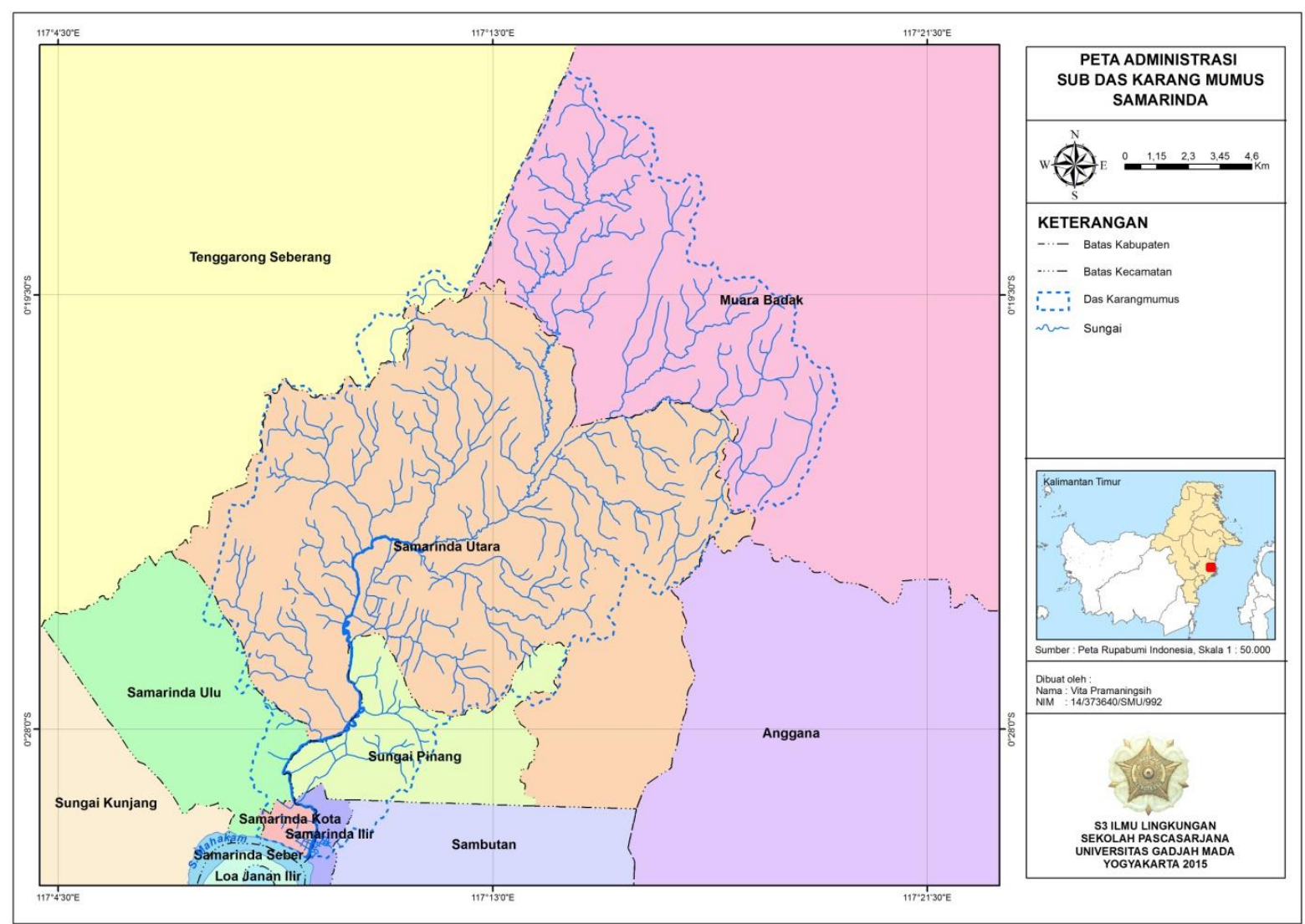

Gambar 1. Peta Lokasi Penelitian

Metode yang digunakan dalam penelitian adalah observasi lapangan, sampling air dan pemeriksaan laboratorium. Observasi dilakukan dengan pengamatan dan dokumentasi. Sampling air dilakukan pada 17 titik secara berurutan dari hulu hingga hilir. Analisis BOD, COD dan TSS dilakukan di Laboratorium Kesehatan Daerah Provinsi Kalimantan Timur. Hasil laboratorium dianalisis sesuai dengan standar PERDA KALTIM No. 2 Tahun 2011 tentang Pengelolaan Kualitas Air dan Pengendalian Pencemaran Air. Sungai Karang Mumus dibagi menjadi 5 segmen berdasarkan potensi sumber pencemar. Titik pengambilan 212 sampel dilakukan pada 7 titik di sungai utama (A1..A7) dan 10 titik (B1-B10) di anak sungai dan drainase. Persebaran spasial pencemaran dianalisis dengan program ArcGIS, sehingga dapat dipetakan lokasi pencemar dan potensi sumber pencemar.

\section{Hasil dan Pembahasan}

Berdasarkan hasil penelitian menunjukkan kualitas air sungai untuk parameter BOD, COD dan TSS dari hulu hingga hilir pada beberapa segmen telah melebihi standar. Hal ini dipengaruhi oleh kegiatan masyarakat 
di bantaran sungai. Hasil analisis laboratorium kualitas air Sungai Karang Mumus untuk parameter BOD,
COD dan TSS dari hulu hingga hilir, disajikan pada Tabel 1, Tabel 2 dan Tabel 3.

Tabel 1. Kadar BOD Sungai Karang Mumus Tahun 2016

\begin{tabular}{|c|c|c|c|c|c|c|}
\hline No. & Lokasi & Kode & BOD $(\mathbf{m g} / \mathbf{L})$ & $\begin{array}{c}\text { Standar } \\
\text { BOD }(\mathrm{mg} / \mathrm{L})\end{array}$ & $\begin{array}{l}\text { Segmen } \\
\text { Sungai }\end{array}$ & $\begin{array}{l}\text { Potensi Sumber } \\
\text { Pencemar }\end{array}$ \\
\hline 1 & Jembatan setelah Waduk Benanga & A1 & 17,1 & 3 & \multirow{4}{*}{1} & \multirow{4}{*}{$\begin{array}{l}\text { Pemukiman dan } \\
\text { ladang }\end{array}$} \\
\hline 2 & Sungai Lempake Jaya & B2 & 17,1 & 3 & & \\
\hline 3 & Sungai Bengkuring & B3 & 38 & 3 & & \\
\hline 4 & Jembatan Tepian Lempake & A2 & 20,9 & 3 & & \\
\hline 5 & Sungai Mugirejo-Gn. Lingai & B4 & 7,6 & 3 & \multirow{2}{*}{2} & \multirow{2}{*}{$\begin{array}{c}\text { Pemukiman dan pasar } \\
\text { tradisional }\end{array}$} \\
\hline 6 & Gunung Lingai (Jl. P.M. Noor) & A3 & 13,95 & 3 & & \\
\hline 7 & Sungai Sempaja & B5 & 16,2 & 3 & \multirow{4}{*}{3} & \multirow{4}{*}{ Padat pemukiman } \\
\hline 8 & Drainase A.Yani (Gelatik-Pemuda) & B6 & 15,2 & 3 & & \\
\hline 9 & Sungai Pramuka-UNMUL & B7 & 9,5 & 3 & & \\
\hline 10 & Jembatan Gelatik & A4 & 9,5 & 3 & & \\
\hline 11 & Drainase Lembuswana-Vorvoo & B8 & 23,4 & 3 & \multirow{3}{*}{4} & \multirow{3}{*}{$\begin{array}{c}\text { Padat pem- } \\
\text { ukiman,Mall, Hotel, } \\
\text { Pasar, padat pem- } \\
\text { ukiman di bantaran } \\
\text { sungai }\end{array}$} \\
\hline 12 & Jembatan S. Parman & A5 & 12,55 & 3 & & \\
\hline 13 & Jembatan Perniagaan & A6 & 10,8 & 3 & & \\
\hline 14 & Drainase J1. Gatot Subroto & B9 & 22,8 & 3 & \multirow{4}{*}{5} & \multirow{4}{*}{$\begin{array}{l}\text { Padat pemukiman, } \\
\text { Mall dan Hotel }\end{array}$} \\
\hline 15 & Drainase J1. Lambung Mangkurat & B10 & 39,9 & 3 & & \\
\hline 16 & Drainase P. Hidayatullah & B11 & 12,6 & 3 & & \\
\hline 17 & Jembatan Sei Dama & A7 & 9 & 3 & & \\
\hline
\end{tabular}

Keterangan: A = Sungai Utama ; B = Anak Sungai dan Drainase

Tabel 2. Kadar COD Sungai Karang Mumus Tahun 2016

\begin{tabular}{|c|c|c|c|c|c|}
\hline No. & Kode & COD $(\mathrm{mg} / \mathrm{L})$ & $\begin{array}{c}\text { Standar } \\
\text { COD }(\mathrm{mg} / \mathrm{L})\end{array}$ & $\begin{array}{l}\text { Segmen } \\
\text { Sungai }\end{array}$ & $\begin{array}{l}\text { Potensi Sumber } \\
\text { Pencemar }\end{array}$ \\
\hline 1 & A1 & 26,21 & 25 & \multirow{4}{*}{1} & \multirow{4}{*}{ Pemukiman dan ladang } \\
\hline 2 & $\mathrm{~B} 2$ & 24,99 & 25 & & \\
\hline 3 & B3 & 72,23 & 25 & & \\
\hline 4 & $\mathrm{~A} 2$ & 40,21 & 25 & & \\
\hline 5 & B4 & 17,66 & 25 & \multirow{2}{*}{2} & \multirow{2}{*}{ Pemukiman dan pasar tradisional } \\
\hline 6 & A3 & 31,9 & 25 & & \\
\hline 7 & B5 & 35,7 & 25 & \multirow{4}{*}{3} & \multirow{4}{*}{ Padat pemukiman } \\
\hline 8 & B6 & 27,59 & 25 & & \\
\hline 9 & B7 & 21,83 & 25 & & \\
\hline 10 & A4 & 15,61 & 25 & & \\
\hline 11 & B8 & 61,53 & 25 & \multirow{4}{*}{4} & \multirow{4}{*}{$\begin{array}{c}\text { Padat pemukiman,Mall, Hotel, } \\
\text { Pasar, padat pemukiman di bantaran } \\
\text { sungai }\end{array}$} \\
\hline 12 & A5 & 22,26 & 25 & & \\
\hline 13 & A6 & 21,12 & 25 & & \\
\hline 14 & B9 & 35,57 & 25 & & \\
\hline 15 & B10 & 66,88 & 25 & \multirow{3}{*}{5} & \multirow{3}{*}{ Padat pemukiman, Mall dan Hotel } \\
\hline 16 & B11 & 16,99 & 25 & & \\
\hline 17 & A7 & 17,87 & 25 & & \\
\hline
\end{tabular}

Keterangan: $\mathrm{A}=$ Sungai Utama $; \mathrm{B}=$ Anak Sungai dan Drainase

Tabel 3. Kadar TSS Sungai Karang Mumus Tahun 2016

\begin{tabular}{|c|c|c|c|c|c|}
\hline No. & Kode & TSS (mg/L) & $\begin{array}{c}\text { Standar } \\
\text { TSS(mg/L) }\end{array}$ & $\begin{array}{c}\text { Segmen } \\
\text { Sungai }\end{array}$ & $\begin{array}{l}\text { Potensi Sumber } \\
\text { Pencemar }\end{array}$ \\
\hline 1 & A1 & 9,8 & 50 & \multirow{4}{*}{1} & \multirow{4}{*}{ Pemukiman dan ladang } \\
\hline 2 & $\mathrm{~B} 2$ & 56,4 & 50 & & \\
\hline 3 & B3 & 18,8 & 50 & & \\
\hline 4 & $\mathrm{~A} 2$ & 9,2 & 50 & & \\
\hline 5 & B4 & 15,8 & 50 & \multirow{3}{*}{2} & \multirow{3}{*}{ Pemukiman dan pasar tradisional } \\
\hline 6 & A3 & 10,2 & 50 & & \\
\hline 7 & B5 & 13,6 & 50 & & \\
\hline 8 & B6 & 9,2 & 50 & \multirow{3}{*}{3} & \multirow{3}{*}{ Padat pemukiman } \\
\hline 9 & B7 & 9 & 50 & & \\
\hline 10 & A4 & 9,8 & 50 & & \\
\hline 11 & B8 & 125,6 & 50 & \multirow{4}{*}{4} & \multirow{4}{*}{$\begin{array}{c}\text { Padat pemukiman,Mall, Hotel, } \\
\text { Pasar, padat pemukiman di bantaran } \\
\text { sungai }\end{array}$} \\
\hline 12 & A5 & 6,6 & 50 & & \\
\hline 13 & A6 & 22,2 & 50 & & \\
\hline 14 & B9 & 33.6 & 50 & & \\
\hline 15 & $\mathrm{~B} 10$ & 91 & 50 & \multirow{3}{*}{5} & \multirow{3}{*}{ Padat pemukiman, Mall dan Hotel } \\
\hline 16 & B11 & 14,4 & 50 & & \\
\hline 17 & A7 & 19 & 50 & & \\
\hline
\end{tabular}


Kadar BOD di seluruh segmen pada Gambar 2 menunjukkan hasil melebihi standar. Hal ini merupakan indikator perairan tercemar. Aktivitas biologi terjadi di perairan untuk mengurai bahan organik darilimbah domestik.

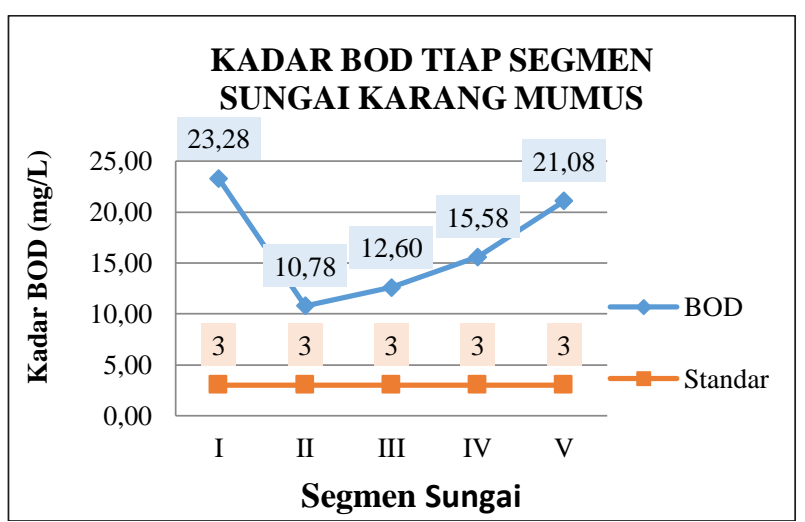

Gambar 2. Grafik Kadar BOD Tiap Segmen Sungai Karang Mumus

Segmen 1 potensi sumber pencemar berasal dari kegiatan perladangan dan pemukiman, karena daerah tersebut berada di daerah hulu Sungai Karang Mumus. BOD tinggi dimungkinkan akibat proses biologi di hulu sungai yang merupakan sebuah waduk, industri tahu tempe skala rumah tangga di pinggir sungai (daerah A3 dan B5) dan pemukiman (daerah B3). Kondisi waduk sangat memprihatinkan karena tertutup tumbuhan air dan terdapat keramba ikan. Proses eutrofikasi atau blooming algae terjadi di waduk akibat banyaknya nutrisi bahan organik dan sisa makanan dan kotoran ikan dari keramba.

Aktivitas masyarakat dalam kegiatan sosial, ekonomi memberi dampak meningkatnya kandungan nutrisi pada sungai dan waduk yang mengakibatkan pertumbuhan pesat tumbuhan air (eutrofikasi) (Oberholsteret al., 2008). Kandungan Nitrogen dan Phospor tinggi di daerah muara sungai dan danau yang menyebabkan eutrofikasi dan menurunnya kualitas air (Conley et al., 2009).Industri tahu tempe skala rumah tangga membuang limbahnya langsung ke sungai dan pemukiman dengan limbah domestiknya termasuk laundry. Sedangkan pada segmen 5 terletak di hilir sungai yang padat pemukiman sehingga banyak limbah organik yang dibuang ke sungai.

Kadar COD di beberapa segmen pada Gambar 3 menunjukkan hasil melebihi standar. Hal ini merupakan indikator perairan tercemar. Kadar COD tinggi pada segmen 1, segmen 4 dan 5 Hal ini terjadi karena bagian hulu dipengaruhi eutrofikasi waduk dan bagian hilir dipengaruhi oleh padatnya pemukiman dengan limbah domestik.

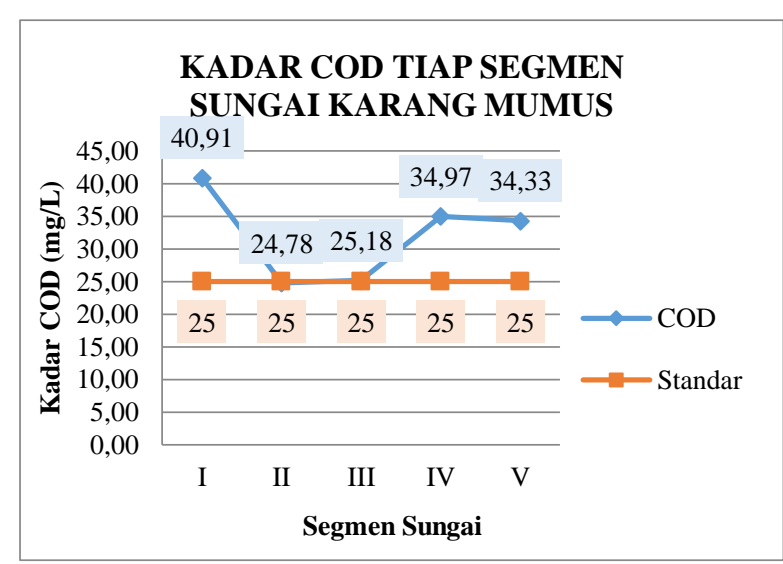

Gambar 3. Grafik Kadar COD Tiap Segmen Sungai Karang Mumus

Kadar TSS pada Gambar 4masih dibawah standar, hanya di segmen 4 sedikit melampaui standar $d$ an segmen 5 mendekati standar. Hal ini terjadi karenaa pada segmen 4 dan 5 merupakan bagian hilir sungai yang dipadati pemukiman dengan limbah domestik. Hasil degradasi limbah domestik menghasilkan partikel solid terutama dari aktivitas Mandi, Cuci, Kakus (MCK). Segmen 4 padat dengan pemukiman di bantaran sungai lengkap dengan aktivitas MCK, terdapat pasar induk, aktivitas yang bergerak di bidang jasa seperti Hotel, Mall, RS dan merupakan pusat Kota Samarinda.

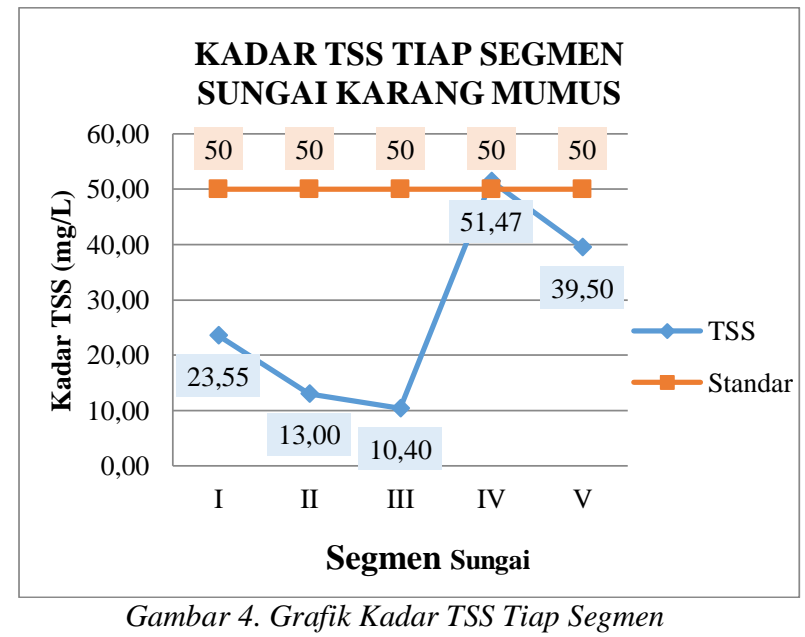

Sungai Karang Mumus

Persebaran spasial untuk parameter pencemar BOD, COD dan TSS disajikan untuk memperjelas lokasi secara spasial pencemaran dan mengidentifikasi aktivitas yang ada di sekitar segmen sungai. Hal ini diperlukan untuk penanganan pengendalian pencemaran Sungai Karang Mumus. Persebaran Spasial parameter BOD di Sungai Karang Mumus dari hulu hingga hilir, disajikan pada Gambar 5. Persebaran Spasial parameter COD di Sungai Karang Mumus dari hulu hingga hilir, disajikan pada Gambar 6.Persebaran Spasial parameter TSS di Sungai Karang Mumus dari hulu hingga hilir, disajikan pada Gambar 7. 


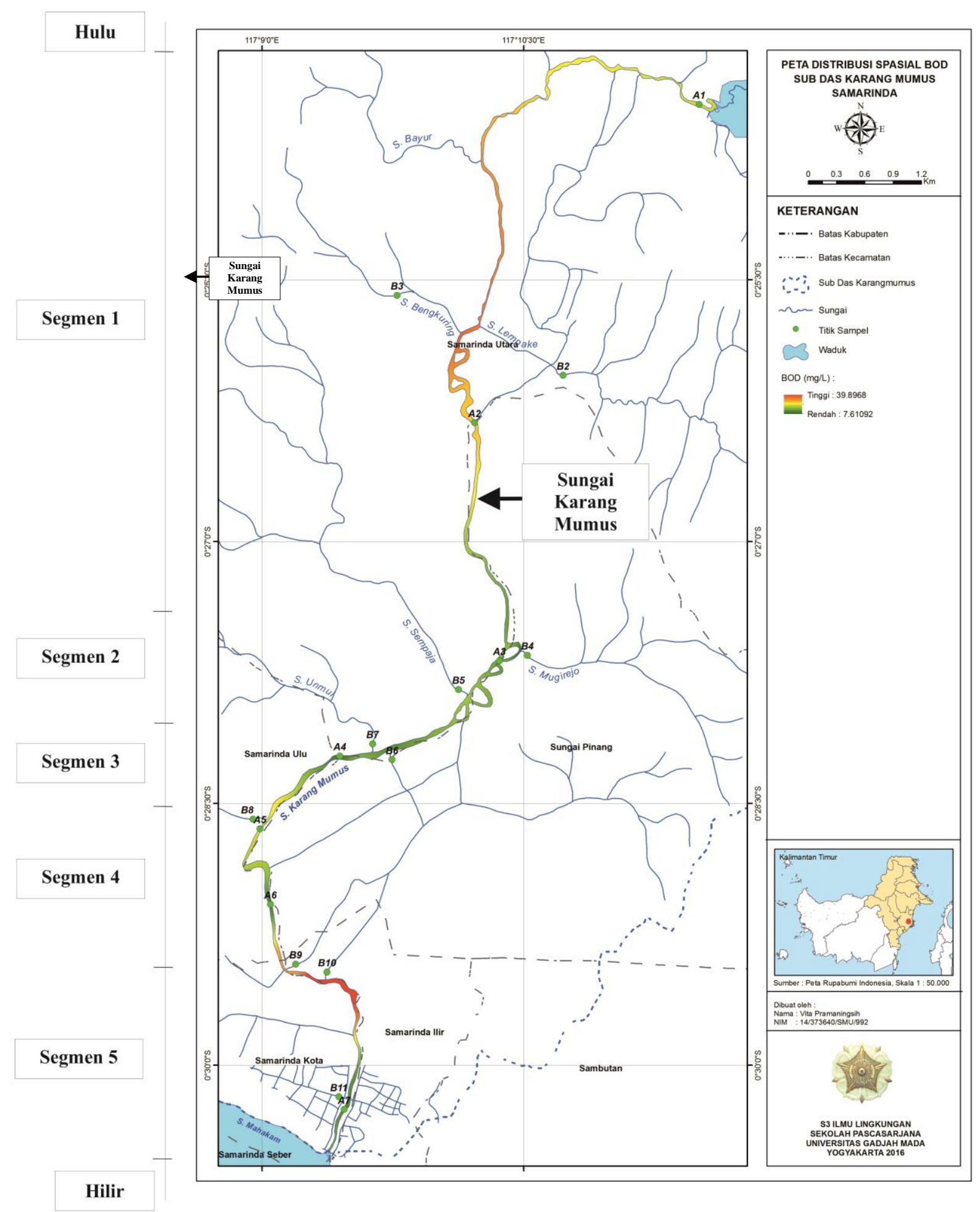

Gambar 5. Persebaran Spasial parameter BOD di Sungai Karang Mumus dari hulu hingga hilir 


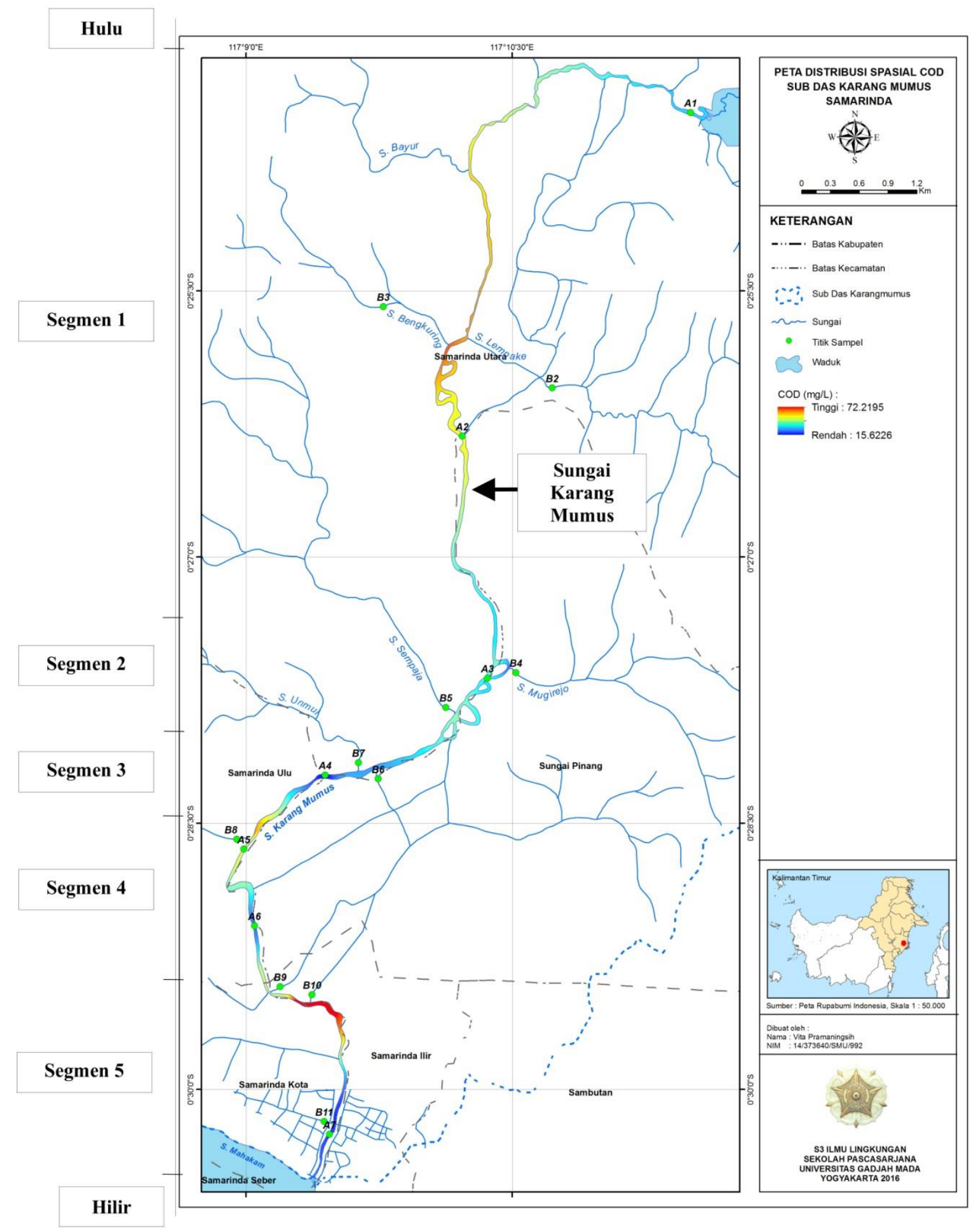

Gambar 6. Persebaran Spasial parameter COD di Sungai Karang Mumus dari hulu hingga hilir 


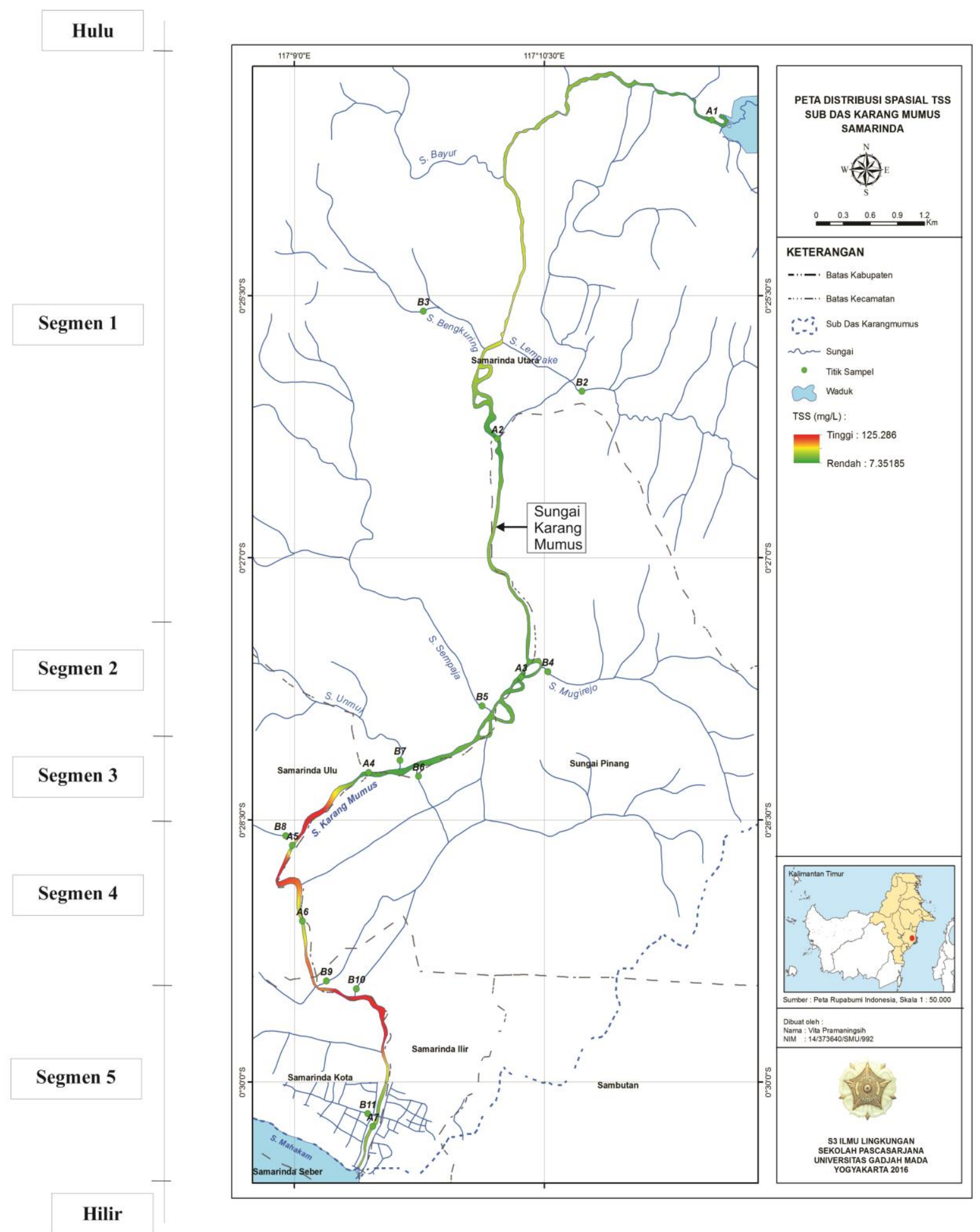

Gambar 7. Persebaran Spasial parameter TSS di Sungai Karang Mumus dari hulu hingga hilir

\section{Kesimpulan}

Persebaran spasial BOD dan COD tinggi di daerah hulu dan hilir, sedangkan TSS tinggi di daerah hilir. BOD, COD dan TSS tinggi di daerah yang padat pemukiman terutama di daerah bantaran sungai, industri rumah tangga tahu tempe, daerah perkotaan, pasar, RS dan Mall. Aktivitas tersebut menghasilkan limbah domestik yang dibuang ke sungai.

\section{Daftar Pustaka}

[1] Conley, D.J., H.W.Paerl, R.W.Howarth, D.F.Boesch, S. P. Seitzinger, K. E. Havens, C. Lancelot, G.E. Likens, 2009.Controlling Eutrophication: Nitrogen and Phosphorus, SCIENCE, 323, 20 February 2009 (www.sciencemag.org)

[2] Effendi, Hefni, 2015. River Water Quality Preliminary Rapid Assessment Using Pollution Index, Elsevier B. V. Procedia Environmental Sciences. 33(2016), pp. 562-567.

[3] Kalavaty, S., Sharma, T. R., Sureshkumar, P., 2011.Water Quality Index of River Cauvery in Tiruchirappalli District, Tamilnadu, Arch. Environ. Sci. (2011), 5, pp. 55-61. 
[4] Kanu, O.K. Ijeoma, 2011, Industrial Effluents and Their Impact on Water Quality of Receiving Rivers in Nigeria. Journal of Applied Technology in Environmental Sanitation. 1(1), pp. 75-86.

[5] Kumar, A., B.S. Bisht, V.D. Joshi, A.K. Singh, A. Talwar, 2010, Physical, Chemical and Bacteriological Study of Water from Rivers of Uttarakhand, J. Hum. Ecol. 32(3), pp. 169-173.

[6] Oberholster, P. J., Ashton, P. J., 2008, An Overview of the Current Status of Water Quality and Eutrophication in South African Rivers and Reservoirs, State of the Nation Report, Parliamentary Grant Deliverable.

[7] PERDA KALTIM No. 2 Tahun 2011 tentang Pengelolaan Kualitas Air dan Pengendalian Pencemaran Air.

[8] Sumendar, R., 2012, Pengaruh Limbah Cair Kegiatan Tambang Batubara Terhadap Kualitas Air Sungai Karang Mumus Kalimantan Timur, Fakultas Geografi, Universitas Gadjah Mada, Yogyakarta.

[9] Venkatesharaju, K., P. Ravikumar, R. K. Somashekar, K.L. Prakash, 2010. Physico-Chemical and Bacteriological Investigation on the River Cauvery of Kollegal Stretch in Karnataka, Kathmandu University. Journal of Science, Engineering and Technologi. 6(1), pp. 50-59.

[10] Yadav, S.S. and K. Rajesh, 2011, Monitoring Water Quality of Kosi River in Rampur District, Uttar Pradesh, India, Advances in Applied Science Research. 2(2), pp. 197-201.
[11] Yisa, J. and T. Jimoh, 2010, Analytical Studies on Water Quality Index of River Landzu. American Journal of Applies Sciences. 7(4), pp. 453-458.

[12] Yogendra, K. and E.T. Puttaiah, 2008, Determination of Water Quality Index and Suitability of an Urban Waterbody in Shimoga Town, Karnataka, Proceedings of Taal 2007: The $12^{\text {th }}$ World Lake Conference. pp. 342-346.

[13] Yuliana, I., 2013, Studi tentang Pengetahuan Masyarakat terhadap Kondisi Lingkungan Pemukiman Penduduk di Bantaran Sungai Karang Mumus, eJournal Sosiatri-Sosiologi, 2013, 1(1), pp. 20-30.http://e-journal.sos.fisip-unmul.org.

[14] Yumita, N.D.S., L. Sina, K.W. Wardana, 2014, Tinjauan Yuridis Dampak Relokasi Warga terhadap Lingkungan Hidup di Sungai Karang Mumus Kecamatan Samarinda Ilir, Jurnal Beraja Niti ,3(3). http://ejournal.fhumnul.ac.id/index.php/beraja 